\title{
The paradoxes of gerotranscendence: The theory of gerotranscendence in a cultural gerontological and post-modernist perspective
}

\author{
Kirsten Thorsen, Cand. psychol., Dr. Philos. \\ NOVA - Norwegian Social Research, Munthesgt. 29, 0260 Oslo, Norway \\ Telephone +4722541263 Telefax +4722541201 E-mail kirsten.thorsen@isaf.no
}

\begin{abstract}
This article presents a theoretical analysis and discussion of the theory of gerotranscendence, formulated by Lars Tornstam (University of Uppsala, Sweden). The theory is presented as a meta-theory of ageing, as a theory of universal and general ageing processes. Ageing is seen as an urge (a drive) towards a less engaged posititon in the wordly life, moving towards a higher degree of transcendence, with a more cosmic outlook and another definition of reality. In this article the theory is discussed from another theoretical position; Ageing seen in a cultural gerontological perspective, as a varied culturally and historically situated phenomenon - differing in different times and different cultures. The theoretical perspective underlines that ageing is complex dialectical processes, an intertwined interplay between individual development and cultural change. The varied individual ageing processes are not seen as the result of «drives». In Western post-modern cultures the ageing processes are becoming manifold, often contradictory. Elderly present versions of the selves that are becoming complex, multiplied (multiple selves), acting at different scenes, stamped by varied cultural values, presenting mixed versions of activity and passivity, engagement and retractment, wordliness and transcendence.
\end{abstract}

Key words: Ageing theories; gerotranscendence; cultural gerontology; postmodernism

\section{INTRODUCTION}

What theories does gerontology need? Is it grand theories of general, universal ageing or theories of a more limited scope that focus on specific themes or aspects of the ageing process? And where do current theories stand in relation to the scholarly debate and the development of theories in disciplines that are part of the cross-disciplinary panorama of social gerontology such as sociology, psychology and anthropology?

This article discusses Lars Tornstam's theory of gerotranscendence in a culture-gerontological and post-modernist perspective. It includes a theoretical discussion of what I call the "paradoxes of gerotranscendence".

Tornstam's theory of gerotranscendence reflects an ambition to develop "a grand theory" - a meta-theory - of ageing. It is put forward with a critical - and selfcritical - look at the development of gerontological theory and its pendulum swings. He places himself as an earlier proponent of theoretical trends which, wellmeaningly and optimistically, have emphasised possibly over-emphasised - old people's resources and need for activity. What myths are to be found in development of gerontological theory, and what do they express? He makes an attempt to remove the scholar's blinkers - which can block both one's outlook and insight. The researchers' perspectives may be at odds with the experiences and views of the elderly; it expresses how scholars wish to view them (Tornstam 1991, p. 112). Tornstam asks whether scholars are engaged in myth creation without being aware of it, and he searches for the blindspots of gerontology's theoretical (self-)reflection.

In this article I focus on Tornstam's theoretical formulations, particularly in his early works (1) on gerotranscendence.

\section{"THE GRAND GERONTOLOGICAL THEORIES"}

Grand theories of gerontology are few in number. The disengagement theory was the first comprehensive gerontological theory of ageing, tentatively launched by Cumming and associates in 1960, and subsequently developed (Cumming \& Henry 1961, Cumming 1963). This theory asserted that people have a "drive" to withdraw from society when they grow old. It saw ageing as a natural, inevitable, universal and functional process: a breaking away from society as a gradual prepa- 
ration for the final exit - death. It is a mutual process in the relationship between society and the individual, which "detaches" the elderly person. This is not seen as a negative process for the old person; on the contrary it is accompanied by satisfaction if allowed to run its course unimpeded. Hence the withdrawal has a societal, a social and a psychological aspect, with a biological foundation. The theory is a "harmony or equilibrium" model for what is seen as and the "natural" ageing process, at the same time socially functional. As such it does not call for criticism of the way the elderly are treated in society: expulsion/withdrawal is simply a social adjustment to a "natural" need. The elderly gradually turn «inwards», and retract from the outer scene. The retreat is experienced as satisfying. Cumming (1963) subsequently modified her theory, pointing out that the disengagement process varies from person to person.

The disengagement theory came under attack from adherents of what has been termed the activity theory, which can be seen as a mixture of an elderly policy manifesto, a social political stance and hypothesis rather than as a coherent theory. It attributed elderly persons' withdrawal to society's expulsion of the elderly, a phenomenon scholars, regardless of theoretical leaning, agree takes place. Expulsion is an expression of "ageism" and discrimination of the elderly. Old peple would probably have continued their activities largely as before had it not been for expulsion by society and age-related social losses. Moreover, activity was seen as healthy and good for body and soul. The activity theory was in keeping with a humanist view of the elderly's situation and with the humanistic research tradition. The theory was subsequently refined and empirically modified to take account of whether activities express continuity or discontinuity, are voluntary or enforced, whether they are desired or not, and, finally, to take account of what meaning the elderly assign to them. Tornstam asks whether the activity theory was formulated too comprehensive, whether its pendulum swings were excessive. It became what Gert Sundström has termed "a houp-la theory of ageing" (1994): an ideal, a programme and myth creation all at once.

\section{TORNSTAM'S META-THEORY}

At this point Lars Tornstam raises the mirror and asks: Can we be sure that the elderly want to be as active as possible in old age, or is it rather the case that younger people's - the scholars' - activity ideals and demands are applied uncritically to old people? Do we, in our well-intended zeal, ignore and overlook their desires for more peace and quiet and reflection, and their need for less involvement and participation in the throbbing human tide?

Or as an elderly schoolmistress I interviewed in the Nordic life-history project (2) said when I asked what had been the most important thing in her life:
"I don't know, I suppose you could say my work, being made use of. Now I have the feeling that I don't want to be made use of. It hasn't always been like that (...)

I think earlier on I couldn't imagine a time when I wouldn't be learning something new. (...) When I wouldn't be taking a stand. It's something you have to do all the time, either at work or in a club or an association. Now I'd rather not take a stand. It's bound to have something to do with ageing."

Tornstam launches his meta-theory of gerotranscendence with a basis in this kind of questions. His approach and his theoretical turn may be provocative, both because his perspective is contrary to an extensive research tradition, to politico-social ideals of integrating the elderly and health-policy endeavours to activate them. It is a bold initiative.

\section{A THEORY OF DRIVE}

According to Tornstam's theory gerotranscendence is a universal phenomenon which expresses normal ageing; "at the same time, we believe that this process is generated by normal living. The very process of living an everyday life and the intrinsic drive towards transcendence are only different sides of the same coin. In principle, we believe that the process towards gerotranscendence is a lifelong and continuous one. In practice, however, it can be obstructed or accelerated." (Tornstam 1989, p. 59).

Tornstam's thinking on gerotranscendence harks back to C.G. Jung (1960) and the collective unconscious: "referring to the fact that we have inherited structures in our minds that are reflections of the experiences of earlier generations. The collective unconscious embraces structures that unify generations and individuals. There are no borders between individuals, generations or places." (Ibid, p. 58).

He is also preoccupied with Zenbuddhism's "transcendent" life experience.

Hence we have before us gerotranscendence as a universal phenomenon that is "naturally", biologically implanted in our consciousness as a "drive". Here Tornstam plays on the ambiguity of the concept of drive (see i.a. Gergen 1991), in the way Freud also applied it: both as a biological urge and a psychic energy.

In other words Tornstam is putting forward an essentialistic meta-theory which asserts the existence of universal biologically founded laws of human ageing. In this respect he is in line with the disengagement theory. He also considers, like Cumming, that "this process is intrinsic and culture free, but modified by specific, cultural patterns" (Ibid, p. 59). The theory's postulate of an intrinsic drive becomes a paradoxical theoretical position inasmuch as he concurrently emphasises that our knowledge of the elderly is relative (1991, p. 105), historical and culture-dependent. Paradigm changes generally coincide with changes in historical-cultural ways of thinking and changes in value patterns. 
The notion of what is "natural" and «normal» varies with historical epoch. The very term is a social construct, a particular way of interpreting a phenomenon. This too has a bearing on Tornstam's meta-theoretical ambition. His position is no more «legitimate» than others', nor does his argumentation have advantages that put him above other theoretical positions and above a culture-dependent understanding of the "normality" of ageing. What may be empirically a dominant phenomenon - «normal» - in no way "proves" the existence of an instinctual, general gerotranscendence process.

Through his theory of gerotranscendence Tornstam wishes to be both anti-positivistic (1992, p. 294) and essentialistic, universal and relativistic, phenomenological and genetic/biological, individualising and collectivistic. But is this possible? Can these perspectives be united? What reasoning justifies a metatheoretical position?

\section{A METAPHYSICAL META-STATE?}

Let us first take a closer look at how the phenomenon of gerotranscendence is described. It is referred to in an "elevated" language, rather like a higher level of cognition. Transcendence means "crossing over" to another stage, another sphere, another form. It entails abandoning the old cognition for an entirely "new" one. Indeed Tornstam describes it as a higher sphere: "Some of us might even reach a higher degree of transcendence, entering a new meta-world with new definitions of reality. These definitions might seem to be much more cosmic than the "normal" definitions held by social gerontologists" (1991, p. 59).

We see here a suggestion that spheres of cognition coincide: the elderly attains a "meta-world", just as the scholar arrives at a meta-theory. Through the use of the meta concept, the scholar and the object of his research are seemingly located at the same level - both have attained a higher stage of cognition (3).

The gerotranscendent state is described almost as a metaphysical state - in a third meaning of the metaconcept. With reference both to Jung and Zenbuddhism the state is encircled with words such as "spirit", "boundless", "merging" (Tornstam 1989). The most adequate term for capturing the state when it "culminates" appears to be the word cosmic which is repeated at several points (Ibid. p. 59). "The enhanced feeling of a cosmic communion with the spirit of the universe can be experienced as being part of a flow energy which courses through the Universe" (Ibid, p. 60).

Hence we find in the gerotranscendent state a merging of "energies" - the biological drive, the psychological striving and the cosmic energy: a parallel use of flow terms from various spheres in which it is primarily the terms' metaphorical similarity that gives the impression of merging and unity.

A more down-to-earth question is the culturalrelative one: how do notions of cosmic spirits and forces relate to familiar, widespread ideas in the community? Anthropologists and scholars of religion have shown the great variation between and within different cultures in terms of the subject-matter of such ideas and how they are incorporated and institutionalised. Notions of cosmic spiritual relations are obviously culture-dependent.

Tornstam cites the Druzes (4) as an example of a community in which the transcendence of old age are central to the organization and functioning of the society.: "...in the Druze world religious ceremonies provided a social arena for the wisdom of gerotranscendence" (Ibid p. XX). It should be pointed out that the religious ceremonies described are conducted by and involve the Druze men. It is the men's "gerotranscendence" that is described. The same example shows spirituality's two-sidedness - not just an increasing spiritual striving is in evidence, but also an increase of worldly power. Through their exercise of religion the Old Men acquire power over younger men. The transcendence is rewarded in this life. It provides a masculine confirmation of power. Hence a "cosmic" experience becomes culture-dependent both in content and distribution, impeded or promoted by cultural position, with associated "rewards", as entailed by transcendent beliefs.

\section{AWAY FROM MATERIALITY?}

In the course of the gerotranscendence process there is a change to another form of rationality. The shift in the elderly's meta-perspective entails a shift from a materialistic and rational to a cosmic and transcendent way of thinking (Ibid, p. 60). This is called wisdom, Tornstam emphasizes.

The word materialistic can be given various meanings. It can mean "accumulating worldly goods", being preoccupied with "things", procuring/possessing material assets. It can also involve a desire for positions of power. To return to the Druzian example: the cosmic outlook in old age gave the right of disposal of the religious symbolic objects and access to religious/ worldly positions of power. Other examples are earlier historical experiences of the church - with its "transcendent" men - which rather often does not seem to have despised power and possessions, but to have acquired such with energy and efficiency. Modern gurus of various faiths seem to have an equally well developed feeling for this-worldly materialism as for other-worldly spirituality.

On a more modest scale, many elderly do not seem to be averse to material interests, but in a different way than younger people (5). They no longer buy so many new items as in younger times. They are still not an important target group for advertisers, but they quietly save in the bank, accumulate wealth and security - a "risk capital" and an inheritance for their heirs. This concurrently becomes a monument to a long working life and symbolises having "settled one's accounts" (6). 
Elderly persons' reduced eagerness to buy, their established position and accumulated capital are at the same time "rational" in a situation in which they have acquired what they need in the way of material assets and see less need for current consumption (7). A diminishing interest in consumption can also be seen as a phase-of-life phenomenon, not as a biological drive towards gerotranscendence.

Hellevik (1996) draws an analytical distinction between aspects of materialism such as having material assets (traditional materialists) and wishing to acquire them (modern materialists), and asks how these are related. The typical traditional materialist is usually above 50 years old, often a pensioner. The modern materialist - characterised by the catchwords «own/enjoy» - is typically represented by a worker or a young, unmarried man undergoing education (8); he wants a lot for himself.

There are several points to be noted here - modifying the concept of materialism. One may well be a materialist in one sense (by possessing), but not in another (wanting to acquire). One may be a materialist (in the event possessing a lot), but subjectively tone down this aspect. Material consumption becomes less important in line with the "principle of falling marginal utility". Subjectively further wealth may count less (verbally) for someone who has a lot or has what he needs. This need not mean that one in practice (in habits and actions) is not equally materialistic as previously (9). Both theoretically and empirically it is conceivable that elderly people are both materialistic - in specific senses - and have become more "spiritual" in their propensities. Perhaps they simply see themselves as more spiritual/cosmic now than previously, not necessarily because they have become so, but because they feel less materialistically oriented than previously. The "eagerness to acquire" has subsided. An alternative or concurrent explanation is that old people adapt to the constraints of a new situation; they are less materialistic simply because they have less opportunity to be so owing to reduced income.

Given the theory's universal aspirations, it is - in a culture-relativistic perspective - worth recalling studies of gatherer cultures where neither young people can be said to be "materialistic". Or societies based on gift logic e.g. in the form of Indian potch-latch rituals - where the individual (man) may appear to be nonmaterialistic in his unselfish zeal to give, but where the giver position at the same time expresses power and gives power over the recipient. The gift obliges the latter to give a gift in return if he is to retain his own status. Giving away the most confers the most power. The meaning of materialism is not simple.

\section{A DIFFERENT RATIONALITY OR EMOTIONALITY?}

The same applies to the rationality concept that Tornstam applies. What is the nature of this rationality? Is it a dualistic view of the distinction between feelings and reason, the cognitive and the emotional? Does it embrace rationality of purpose, logical rationality, technical-scientific rationality, or the opposite form of rationality - what has been termed "care rationality" (Wærness 1996)? In a certain sense cognitive reorientation of elderly people, described by Tornstam himself (1978) within a homeostasis model, can be said to be "rational": The essential point is to retain life satisfaction or experienced quality of life. This is done by changing the meaning and weight of various aspects of the life situation. Put simply: what one loses becomes less important. What remains gains yet more importance. Comparisons can also be drawn with selected reference groups to improve one's perceived position: other elderly people are worse off.

Since gerotranscendence is "wisdom", is it another form of rationality, i.e. a meta-rationality or a more emotional way of relating? In the dualism between feelings and rationality, rationality appears in the modern world of ideas as a "higher-ranking" source of experience, feelings as a lower one. Feelings are associated with immaturity, lack of good sense, irrationality, spontaneity, unpredictability, elusiveness (Lutz 1988). Feelings are not to be "trusted" beyond the moment. However, feelings are also viewed as positive - an echo from the Romantic Period. They are life-giving, liberating, sensuous, intoxicating, enriching. Lutz points out that within the modern western view, feelings often acquire both the positive and negative poles of dualism. Feelings also appear as "warmth" and alive vis-à-vis cold and inhuman rationality. Further, feelings are traditionally "female", rationality male. Where does gerotranscendence stand within this dualism? Does it imply a higher form of rationality, of emotionality, or both? Or is dualism irrelevant, as Tornstam would probably claim.

Feelings are emotional constructs that are construed and thematised in accordance with their epoch (10). Bloch (1993) asks the following question in a thought-provoking article: "Has the significance of feelings changed?" A feature of modernity is the individual's liberation - from tradition, duty and rootedness. Wouters (1992) sees the development of feelings' cultural status in recent decades as a "wave of informalisation" that liberates the feelings - also in relation to reason. Feelings - across a broader spectrum - are becoming more legitimate, and they are being allowed a central position in consciousness. New feelings or combinations of feelings are appearing under new designations. A new feeling-related term is "flow". It refers to an experience "of concentration, loss of awareness of time and the self, a perception that everything sounds effortless and where there exists a perfect and enriching harmony between the person and the surroundings ..." (11). This is a description that has many features in common with Tornstam's cosmic experience of gerotranscendence. According to Bloch, flow (and its antithesis "stress") denote experiences 
falling between feelings and moods; "they are more purposeful than moods, which are feelings without an object, and concurrently less purposeful than emotions, which have an object" (p. 84). Once a concept for phenomena within special subgroups of persons, the concept has now acquired general application. Theoretically it belongs in the sphere of life-quality research and is associated with individual strategies for «the good life». Here too there are clear parallels with the gerotranscendental striving.

In a post-modernist perspective it is interesting that, compared with feelings such as shame and pride, flow (and stress) are characterised by the fact that the social context/respondent to which they relate is far more diffuse (12). In other words it is feelings towards people in elusive social relations which are constantly changing, feelings adapted to the post-modern self (Gergen 1991).

My question is the following: Is transcendence "a feeling belonging to its time" - an expression of "postmodernity's spirit» which not only affects old people but all age groups? The content of the experience and the significance it acquires will vary between young people, middle-aged and old people, but much of the cosmic experience - as this is described - may be the same. Here too, a cultural gerontological perspective lends meaning.

\section{A CONTINUOUS DEVELOPMENT, STAGES OR TRANSCENDENCE TO A NEW META- SPHERE?}

In the course of the gerotranscendence process the perception of self also changes. Tornstam refers to Erik H. Erikson's (1968) development model where "ego-integrity" is the goal of old age - and desperation its antithesis. Stages succeed one another in a "natural" and "normal" chain of development, where each stage has its developmental tasks which can be resolved favourably or unfavourably. The subsequent development is based on the solutions reached at earlier stages. In a way this too is a model of ageing entailing a progression to new, higher stages of development.

But Tornstam (1989, p. 59) distances himself from this type of gradual development. He refers to the Druzes' perception of earlier life as "immature". They now live "in another world" than previously. The "stage of gero-transcendence" entails both a transition to a qualitatively quite different sphere - i.e. a radical break with the past - and a gradual evolution. It is primarily crises that trigger the switch to the new "meta-world". Hence it becomes a more total transformation of lifeview suggesting parallels with religious conversion. It is also repeatedly emphasised that a continuous, gradual change is involved, i.e. not a "quantum leap" to an entirely new state, nor a development across stages (1989): "In principle, we believe that the process towards gerotranscendence is a lifelong and continuous one" (p. 59).
This becomes a paradoxical theoretical position, a "both the one and the other" philosophy of what otherwise appear to be different phenomena and processes: on the one hand the continual, the gradual development, and, on the other, the transcendental "leap". Is it possible to conceive of a gradual development to a completely different mode of cognition? Will not gradualness in itself cause the state to be a somewhat changed version of the earlier state, and not appear as radically different? When can continual change be said to have turned into something qualitatively quite different?

\section{FROM COMPACT EGO TO BLURRED SELF?}

Tornstam alternately employs a concept of ego and a concept of self, and he describes a change from a relatively compact, concentrated, self-centred ego to a more open, fluid, blurred self. "The change in the perception of objects can include an elimination of the borders between "you" and "me", and between "us" and "them". An impression of being «one all together» becomes dominant. As a consequence, the degree of self-centeredness will diminish. To a certain extent the enclosed self is disaggregated and substituted with a cosmic self." (1989, p. 60).

The more «open self» has, however, not become more generally open towards other people in general. On the contrary the transcendental elderly person has become more selective in his dealings with others. The person is open towards others with whom it is meaningful to interact, and curtails unessential and unrewarding contact. It is first and foremost in relation to the cosmic universe that the self opens itself - the spiritual, indeterminate feeling of community; "being one and all together" - not in social relations. A prerequisite for this openness of the self towards the cosmic universe is a notion of "the enclosed self" - a perception in keeping with the ego-psychologists' perception of the - as far as possible integrated - ego, where rationality and reason reign. Erikson (1968) is located within this tradition.

This view is in contrast to the self-psychologists' notions of the socially constituted self, a self that is more changing, many-sided, ambiguous. The self becomes less unitary, more "diffuse" and open. This is a theoretical position - a different perception of the self from that of the ego-psychologists (13) - forwarded by post-modernist thinkers such as Giddens (1991), Gergen (1991) and Shotter (1984).

Further, the self is linguistically constructed. The self is at once both relational and self-reflective; outward relating and inward looking. Øvrelid (1986) gives the following summary of the post-modernist (14) perception of self:

"A definitive reckoning has been had with the psychological/sociological "self", the core of our personality which we attain through identification with various role models or through socialisation. With this perspective our identity has become a diffuse multiplicity $(\ldots)$ 
Speaking in more general terms of this tendency in society, this suggests that (post-)modern man appears in a multitude of different social arenas (work, family, leisuretime etc.). Concurrently the media and commercial culture offer an immeasurable range of different "identities" and life-styles to choose from. This impacts on the idea of the fixed personality, and of the old familiar social categories such as gender, class etc. The above diagnosis prompts a focus on what is dissimilar, split-up and fragmentary rather than on what is identical and unifying" (p. 85).

The more diffuse, more open self in this theoretical approach has clear features in common with the fluid self outlined by Tornstam. The difference being that the transcendental self opens itself to a "celestial" spiritual sphere while the relational self is clearly thisworldly in its relations. Hence change from a more «well-defined ego» can be seen in a historical and cultural psychological perspective.

It is not merely a theoretical shift in understanding, but refers to tendencies towards changed selfconstructions in the population. The personality of post-modern times appears as more manifold - with more "selves", which may be different; ambiguously different in different arenas and in different relations. In other words there are both theoretical and culturalhistorical changes in the construction of the self, with clear similarities with what Tornstam describes as an ageing phenomenon; namely a reduced selfcentredness $(1989$, p. 60). This can be described as a transition from a "modern" ego and identity concept to a "post-modern" concept of the self with multiple socially constituted self-constructions. The ego seems to lose its centre, and in this sense the person becomes less self-centred. The tendencies to more "postmodern" self-constructions coincides with the ageing process of elderly today.

The changes will affect different generations' selfunderstanding in different ways. Old people's perception of self will also be influenced by values and attitudes they have adapted earlier in life. These are somewhat different from those influencing younger generations, values which old people in part define in contrast to those of younger generations. The elderly generally define themselves as more «moral» than younger people (Danielsen and Thorsen 1995, Thorsen 1995).

In this complex interplay of cultural change and personal ageing - "the dual change" (Thorsen 1995, 1996) - the elderly too may experience greater openness, more "diffuseness" in the self, possibly with a different content, meaning and direction than among younger people. The differences are characterised by different life-phases and different time perspectives on life. As presented by Tornstam (1992), it is ageing that causes the elderly to feel less distance and blurred boundaries between generations than earlier in life, smaller time-gaps (15) between historical periods, a smaller divide between life and death and between this life and the "universe", less interest in superficial con- tacts and more interest in "the inner world". Possibly younger people (16) will also voice the same claim to be less interested in superficial contacts?

This prompts the question of whether the trend towards a more open, more diffuse self is an ageing phenomenon (the elderly becoming more diffuse), a period phenomenon (everyone becoming more diffuse) or a cohort phenomenon (new cohorts/generations becoming more diffuse). Or is it possibly an interplay between these, with more complex interaction effects and differing meaning assigned by young, middle-aged and old people?

\section{OLD-AGE WITHOUT BODY OR GENDER}

Paradoxically the gerotranscendent person abandons his/her body in old-age. The person becomes more spiritual and less physical/body-preoccupied. Tornstam (1989) cites Peck (1968), who lists the contrasts between body transcendence and body preoccupation. The former denotes positive ageing while the latter is regarded as negative ageing. "Some people become increasingly preoccupied with their bodies" (Ibid, p. 61 ), and "In the same way as the body, the ego should be transcendent in old age" (p. 61). Tornstam underscores Peck's use of the transcendence concept in the direction of overcoming physical pains and fear of death and the future (Tornstam 1989, p. 61). This notion can in a certain sense be seen as a parallel to the disengagement theory: the body is transcended in preparation for death.

This "debodification" of old age can be seen as an illustration of a further paradox - what Peter Øberg (1996) has termed "the social-gerontological paradox". He discusses implications of the concept with a basis in Sharon Kaufmann's book: "The Ageless Self" (1986), summarised in the following quote:

"The old Americans I studied do not perceive meaning in ageing itself, rather, they perceive meaning in being themselves in old age/....../ When old people talk about themselves, they express a sense of self that is ageless an identity that maintains continuity despite the physical and social changes that come with age (17) (Kaufmann 1986: pp. 6-7, Øberg's italics).

Øberg asks the question: What is the ageing process if the self is timeless? He finds the answer in social gerontology's continuation of the western dualistic perception of body and soul/spirit - res extensa and res cogitans. The distinction has roots going back to Plato, Descartes and Christianity, which assert that spirit and idea are what is truly human, and the body subordinate, inferior - indeed a temptation and diversion from the unfolding of the spirit. In research on ageing, the distinction is cemented in the fact that geriatrics concerns itself with physical ageing, and social gerontology with the social and psychological aspects of ageing. The body has - according to him - been rendered invisible in social gerontology (18). This applies not only to the body as a physical organism but also to 
the body's social and cultural significance in society the body as signs, symbol and cultural construct. The ageing body has to a great extent become a non-theme. It is only within such a "spiritualised" perception of ageing that an understanding of "the timeless self" can arise.

I would also point out that it represents an ahistorical and acultural view of ageing - an attempt to place oneself over and outside time, both bodily, spiritually and historically. There are parallels with the timelessness of the «cosmological» self and the bodilessness implied by the gerotranscendence theory. The timeless self expresses an individualistic, delimited, autonomous and self-sufficient self - a "central-core self" which becomes more "its real self" with the passage of time. This ageing self is described by Erikson et al. (1986) in terms of old people "struggling to continue to feel like themselves" (p. 131).

Ageing is often met with negative stereotypes. The person can variously attempt to rise above the passage of time - with the bodily changes and social losses. This can be seen as defence strategies or coping strategies, i.e. as attempts to preserve a positive self-image during the ageing process (Ingebretsen and Thorsen 1990). What Kaufman describes is an attempt to deny ageing by separating out the ageing body as a personal carrier of meaning. It belongs to "the others" with its negative connotations - the true self is timeless. Preserving a «continuous self» - as gerontological continuity theories assert - is the central concern. A self that is as far as possible unchanging, a timeless self, a young self, becomes the ideal. Thus "the timeless self" represents a striving to preserve the self under unfavourable socio-cultural conditions, not the "natural" ageing process. The cosmic, transcendental self can be seen as the culmination of this striving to cope.

To return to the Druzes: "Timeless ageing" entails quite different processes and quite a different cultural interpretation from the view of ageing we find with the Druzes - even though they may seem identical from the outside. Cultural interpretations of old age in these communities differ, and lend meaning to persons' interpretation of themselves as ageing. The old male Druzes acquires power, status and respect by means of their cosmological orientation; the old woman in our culture - to concentrate for a moment on her - attains nothing of this, but rather powerlessness, loss of status and contempt. To relate "cosmically" to one's ageing can be a means of rising above this negative image in our culture. However, the old men in the Druzian villages would probably protest energetically if someone told them that they were timeless - youthful indeed like they were in their youth, unchanged. They have definitively abandoned the "immature self".

Peck (1968) recommends people to tone down the sexual and erotic aspects of life in early "middle age". They should "socialise" instead; Tornstam would probably have said "transcend". Not even the pleasures the body can provide at a mature age should be striven for. This view is not far removed from the abstinence preached by the fathers of the Christian church. Augustin recounts in his Confessions how he struggles to keep the body's (sin's) temptations at a distance. This applies to all pleasures of the senses, both the traditional "sinful" ones and the more innocent ones. "The pleasures hearing can give had gained a powerful grip on me and bent me under their yoke. But you have redeemed me and liberated me. I confess that I still find satisfaction in the melodies to which your words give life and soul when they are sung with finesse by a fine voice ... Hence I sin without noticing it, but afterwards I feel that it is a sin (Conf. X33, quoted after Gaarder 1996, p. 215).

Ageing without a body makes it easier to perceive ageing as genderless. This helps to underpin the picture of general, timeless, universal ageing processes. Both Tornstam and Øberg omit to mention gendered ageing. But the body is certainly gendered - our bodies are not shared, but male and female (19).

Bodily and spiritual ageing interacting in the passage of time - "the dual change" - must necessarily relate to time, both in the way that it affects the body's ageing as physical experience and as a culturally and psychologically interpreted phenomenon. In this perspective we are constantly changing. The challenging question becomes, in a cultural gerontological and cultural psychological perspective, how are we to interpret and relate to our changing in time, with time.

However, post-modernist theory - both in the context of French text-theoretical tradition and in American social constructivism (Gergen 1991, Shotter 1984, Polkinghorne 1991) have forgotten the body in time. The self becomes a momentary self as it appears in changing social relations or "discourses". This is also true of feminist post-structuralists. Bigwood (1991) criticises the latter "for having denaturalised the body and gender in their zeal to avoid essentialism. For them the body is "pure" culture, and gender a fluid, artificial affair" (Fürst 1994, p. 113) (20).

It may be that "debodification" in old age also involves deeper-lying phenomena - a fear of decline and of the transience of existence as this is perceived in western secular cultures. Kristeva (1982) speaks of abjection; man's deepest fear which he carries with him from childhood, the association between mother and the body's transience. It is a question of disgust at the realisation of our own bodiliness, our inevitable surrender to uncontrollable materiality (Fürst 1994, p. 105). In Kristeva's presentation this is a fundamental human reaction - rooted in childhood's mother-child relationship - and not something specific to old age. I would point out that given the strong idealisation of youth we see in western societies, this could intensify both young and old people's distancing from old bodies that are a symbol of the transience of existence. In religions/cultures dominated by ideas of life on earth as a precursor to a better, "higher" life after death, the body's transience is possibly not frightening, but 
something promising. The muslim martyrs reminds us that life's transience is open to various interpretations.

French post-structuralists such as Cicieuz and Kristeva attempt to transcend the dichotomous distinction between spirit/body and subject/object, nature/culture. They employ the pregnant female body to show womanliness's/motherliness's enmeshed web of natureculture. It is a paradox that elderly women - who have to an ample degree lived a motherly life under the ethics of motherhood - lack a language for the bodily aspects of this. Women's life histories largely lack references to the body and bodily unfolding, whereas we find a richer "body language" in male accounts (Thorsen 1992, 1996). It is first and foremost the sickly body that old - and in particular old women have a language for and which they experience as legitimate to talk about. It is the medicine's body. Old women's «bodiliness» is particularly ambiguous; in terms of cultural history they have lived "closer to nature" through their motherhood roles, but without a language to capture the female experiences. Their bodily experiences have been tabooed.

Kristeva (1982), the French linguist and psychoanalyst, calls for a female code of ethics - "beyond the law of the Father", allowing women to participate and to bring in body, language and enjoyment (jouissance).

Gerontology needs theories and concepts that incorporate the ageing body and do not exclude it. There has to be a language that captures the male and female experience - that gives both sexes a language they are familiar with - and can communicate through. It concerns concepts of power and powerlessness, potence and impotence, strength and decline, skin contact and erotic pleasure and privation, the body in closeness and distance, as "gendered" and "ungendered", in its unfolding and its suffering in old age. The point is to give gerontology an understanding of the body that is something else than that based on medicine, disease and medication.

\section{THE NORMATIVE ASPECT}

Gerotranscendence has a strong normative element this "normal ageing process" becomes the good, positive, desirable ageing: "the path to wisdom". It is worded: "Gerotranscendence is not negative. It is the highest level of human development and, as such, positive!" (Tornstam 1989, p. 62). The metaphorical use of higher levels of development has evolutionistic features seen in a biological context; psychologically it reflects thinking based on developmental stages and spiritually it shares features in common with religious notions. It seems as if the gerotranscendence theory contains something of them all. This progression to higher levels should be facilitated and not prevented. The ideas central to gerontology change, as Blaakilde puts it (1994, p. 263): "First the elderly were regarded as wretched. Thereafter the ideal was to make them active, while now, according to the ideas of the latest theory, they are to be assigned wisdom". Regardless of whether or not Tornstam emphasises cultural variation, western culture is first and foremost seen as a brake on the propensity towards gerotranscendence (Blaakilde 1994).

This should be remedied. In a good welfare state tradition, personnel and care workers should be trained to support old people to be able to transcend (Dehlin and Tornstam 1994). Since this is the highest level of development, other modes of ageing may become inferior. Normative assessments readily turn into expressed attitudes. What about old people who at long last can afford to enjoy what a well-filled wallet can offer them in the way of travel, entertainment and pleasure? Should they be protected from the objectionable aspects of these activities by gerontologists whose theory states that this type of ageing is not considered desirable? And what about the eager "keep-fitter" who enjoys the time he - or she - now has to keep the body in trim? In the Norwegian version the highest masculine dream is to depart this life during a walk in the forest or, in the latest contemporary version, during a leisure run in the city centre. A female "post-modern" version is proposed by Åsa Rytter Evensen, who wishes to slip quietly under a table at a fashionable restaurant and expire there. What about all the old people who have discovered the opportunity to take courses, study, take exams - and who eagerly amass this-worldly knowledge and feel no need for cosmic spirituality? These people live in keeping with what should be a "bygone" activity ethos, and seem to be happy doing so.

What about the multiplicity of ageing processes to be seen in human life-courses, the breadth of variation? Tornstam is in the process of creating a new theoretical and normative model of ageing - not over, in a meta-sphere, but instead of and on the same theoretical level as the other theories of ageing he wishes to replace.

\section{CONCLUSION}

In my view the ageing process from adolescence onwards must be seen in the light of the complex relations between cultural change and individual development. Ageing can not be viewed separately from the historical and cultural landscape in which it takes place; ageing takes place in this landscape.

Old people, like young people, are undergoing an individual and social process of change. At the same time individuals of all ages are influenced by changes in the "spirit of the age". Changing cultural ideas leave their stamp both on the individual's world-view and his/her perception of self. Perhaps we have all become more "cosmic" in outlook as the world has shrunk and the universe approaches ever closer?

Hence the self is neither acultural, ahistoric, bodiless and genderless in the ageing process. Men's and women's ageing acquires its meaning - including the 
physical change of the body and spirituality of the mind - from the various ideas about these phenomena that are present in society. Society also contains notions about their normative "appropriateness" to various age groups. The phenomena that Tornstam associates with gerotranscendence are not a universal tendency founded on a drive, but are "situated" processes. Man is enmeshed in and constitutes a part of his cultural surroundings. One is - using Blaakilde's (1994) metaphor - "like a fish in water". However culture is not a simple, but a "hyper-complex" concept (Fink 1988). Meanings are manifold - individual and culture are ambiguous, and relations are full of contradiction, the selves of paradoxes. Culture have local variants, which are in turn variously interpreted by each individual. To grasp various forms and meanings of old age requires a cultural gerontology that views the relationships of meanings and interpretations as socially constituted - as the self is. This view has radical consequences for the shaping of theory.

As Swane (1996, p. 3) puts it: "A new gerontology is on the way which not only accommodates, but indeed focuses on, the elderly's diversity and the contradictory nature and complexity of ageing, and which communicates this multiplicity" (21). In its theoretical version gerotranscendence primarily sees unity - not plurality. Such a perspective on the variations of ageing has consequences for the development of gerontological theory:

"A new gerontology might best tolerate the tension rather than attempting to integrate voice and contact into an analytically unified version of ageing, totalizing experience.

This new gerontology, then, is against theoretical inte- gration (..), its aim, on the other hand, is to make visible the variety, contingency and inventiveness in any and all efforts to present life and, on the other hand, to resist the temptation to put it all together into an analytically consistent and comprehensive framework privileging certain voices and silencing others" (Gubrium 1993, p. 62, quoted after Swane op.cit. p. 36).

This does not mean that only the "minor" theories are left (Øverlid 1996), or only individual life histories. There exist cultural codes of more comprehensive significance, whether they are called "deep structures" or "basic codes" (22). Where the self is concerned, the idea of "self-realisation" (the right to self-realisation) can be seen as a more comprehensive view of this kind (Hansen and Trana 1994), which probably will give new generations of old people different ideals and different meaning to their ageing. But could not gerotranscendence itself - with its many paradoxical positions (23), its "both-and" intentions and its transcending ambition - become more fruitful if it abandons its essentialistic, universal scope? No supporting evidence for this pretension can be produced; it is left to stand as a claim.

A theoretical perspective embracing complex, manifold and contradictory ageing processes among men and women provides opportunities to grasp the variation in coping strategies - in cognitions and emotions of old age - within the codes of meaning of the manifold culture in question. This will make room for old people who are active or passive, participating or withdrawn, cosmic or this-worldly, spry or suffering, patient or complaining, angry or cheerful, gerotranscendent or worldly - old people who alternate between or combine these characteristics, and are manifold in their ageing process.

\section{NOTES}

1. The bibliography includes referrals to Tornstam's publications on gerotranscendence. The present article concentrates on his theoretical formulations and does not deal with Tornstam's subsequent empirical findings from a broad survey study.

2. The Nordic life-history project "Ways of life, ageing and well-being" drew participants from all Nordic countries. The studies were based on (tape-recorded) life histories recounted by old people from all social strata, born between 1905 and 1915 and residing in the Nordic capitals. My doctoral thesis "Gender, life-course and old-age" (1996) is based on analysis of 44 Norwegian life histories. Kirsten Danielsen and Peter Øberg have also based their doctoral work on this material.

3. It is the use of concepts that makes the levels seemingly coincide. However, the theoretical meta-position is, regardless, a different form of cognition from the elderly's "meta-world" - a different "paradigm" from the world experienced by the people who is the object of investigation.

4. Described by Gutman (1976).

5. Hellevik (1996), in a study of value shifts in Norwegian society, has constructed a typology of clusters of attitudes in which "the traditional materialist" constitutes one of the types. The persons are characterised by the ten values with the highest support in the group: Non-self-realisation, reason, traditional gender roles, conformity, tradition, security, materialism, distance, anti-technology and authority. Catchwords are: owning and creating security. A typical representative is a man above the age of 50 with low education, a worker or in- 
sured old-age pensioner. His antithesis is "the traditional idealist", an anti-materialist represented by a woman above the age of 60 .

6. Norwegian investigations show that the elderly are the population group with the greatest average accumulated capital. Moreover old people have the greatest living area per resident and least debt. This is also a form of materiality.

7. The children have left home and are getting established. They are often "the nouveaux poor", with lower consumption income than the elderly. They are the group with the biggest need to acquire possessions for themselves and the family (house, car, items for the children etc.). Elderly parents contribute.

8. Young people are more concerned with the material sides of life than other groups while at the same time they - for the time being - possess less. Young people in the opulent society have not become less preoccupied with material possessions, as Inglehart (1990) claims, but more so - as Hellevik asserts. The young people in the group of "modern materialists" could rather be termed supermaterialists: Hellevik finds only small differences between what "materialists" and "idealists" have in the way of possessions. "Hence we can safely state that materialists so often feel they lack necessary items not because they have less but because they want more" (Hellevik 1996, p. 94). Traditional (older) materialists also want more. It is interesting that they score highest of the four types of materialists on the question "If you could have a wish fulfilled today..."

9. Another example of old people's penchant for «the good life» is the pensioners' villages - where old people enjoy the joys of a life of leisure and the assets a well-filled wallet can provide. This is described by Fragell (1995) in her article "Om kunsten å nyte sitt otium" (On the art of enjoying one's retirement).

10. See the Swedish historian Peter Englund's (1992) description of the cultural and historical position of weeping. Cultural thematisation and "application" of feelings varies.

11. The concept of flow was introduced, according to Bloch (1993), by the humanist psychologist Mihaly Csiksjentmihaly.

12. As Bloch (1993) emphasises with reference to Sheff (1990).

13. With traditions back to Mead (1934). The founder of psychoanalytic self-psychology; Kohut $(1971,1977)$ gradually abandoned ego-psychology's ideas in favour of a more socially constituted self, dependent on "mirroring" other self objects. Gullestad (1992) gives an analysis of Kohut's development of the self concept.

14. Post-modern theory is a generic term encompassing a number of different theoreticians from various disciplines. The French tradition occupies a central position - with theories rooted in and inspired by linguistics and psychoanalysis. Foucault (1974) is a prominent figure, and Lacan (1966) among psychoanalysts.

15. Also emphasised by Erikson (1968). Mellbye (1991) describes how he himself feels more and more affinity with past generations, a feeling of togetherness with persons even from far-off times (with the thrall, Kark), while losing interest in a future of which he will not be part.

16. Younger than 50, which Tornstam sometimes mention as the "ageing threshold".

17. Body transcendence or egooccupation.

18. Øberg cites the major gerontological manuals' lack of entries under "body", "body-image", "appearance" and "physical appearance" etc.

19. Dorthe Søndergaard (1996), in her doctoral thesis "Kroppen som tegn" (The body as a sign), analysed the body's sign aspects, where male and female "signs" among young students can be "mixed" in various ways.

20. Fürst (1994) very thoroughly discusses post-structuralist theories' relationship (or lack of such) to the body.

21. Swane (1996) gives an example of culture-gerontological analysis of dementia in her doctoral thesis.

22. In our day general "interpretation systems" on a societal level are "freedom", "democracy", "capitalism", free trade, market etc.

23. Tornstam finds an exception to this more complicated universe of meaning in his own empirical results, for example that old people become more active socially, but assign social activity less significance. Who does this, how, why, with what intention (1992b)? 


\section{REFERENCES}

Bigwood, C. (1991): Renaturalizing the Body. Hypatia, 6 (3).

Block, C. (1993): Har følelser ændret betydning? Tendens, 5 (2), 79-86.

Block, C. (1994): Er flow moderne? In: Madsen et al. (eds.): Den kultursociologiske omtanke. København: Akademisk forlag.

Blaakilde, A.L. (1994): Som en fisk i vandet - kommentar til teorien om gerotranscendens. Socialmedicinsk tidsskrift, 5-6, 281-283.

Csikszentmihalyi, M. (1992): Flow. København: Munksgaard.

Cumming, E. \& Henry, W. (1961): Growing Old: The process of disengagement. New York: Basic Books.

Cumming, E. (1963): Further thoughts on the theory of disengagement. UNESCO Int Sci J 15, 377-393.

Danielsen, K. og Thorsen, K. (1993): Kroket eller strakt? En analyse av eldres livsløp. In: Wærness, K. Ruth, J.-E. og Tornstam, L. (eds.): Livsløp blant gamle i Norden. NGI-rapport 1-1993. Oslo: Norsk gerontologisk institutt.

Dehlin, O., Tornstam, L. (1994): Aktivering av äldre - nyttig terapi eller förmyndaraktig tvång? Läkartidningen, 91 (44), 3973-3977.

Engelstad, H. (1997): Pensjonisters økonomiske reserver. Aldring \& Eldre, 1, 7-9.

Englund, P. (1992): Fortidens landskap. Oslo: Universitetsforlaget.

Erikson, E.H. (1968): Barndommen og samfunnet. Oslo: Gyldendal Norsk Forlag.

Fink, H. (1988): Et hyperkomplekst begreb. Kultur, kulturbegrep og kulturrelativisme. In: Hauge, H. og Horstbøll, H. (eds.): Kulturbegrebets kulturhistorie. Århus Universitetsforlag, Danmark.

Fragell, K. (1995): Om kunsten å nyte sitt otium. Gerontologiske skrifter nr. 6. Oslo: Norsk selskap for aldersforskning.

Fürst, E. L'Orange (1993): Mat - et annet språk. En studie av rasjonalitet, kropp og kvinnelighet belyst med litterære tekster. Avhandling. Universitetet i Oslo: Institutt for sosiologi.

Gergen, K.J. (1991): The saturated self. Dilemmas of identity in contemporary life. New York: Basic Books.

Giddens, A. (1991): Modernity and Self-Identity. Self and Society in the Late Modern Age. Cambridge: Cambridge University Press.

Gubrium, J.F. (1993): Voice and context in a new gerontology. In: Cole, T.R. et al. (eds.): Voices and Visions of Aging: Toward a Critical Gerontology. New York: Springer.

Gullestad, M. (1992): A si fra-Autonomibegrepet i psykoanalysen. Oslo: Universitetsforlaget (Det blå bibliotek).

Gutman, D. (1976): Alternatives to disengagement: The old men of the Highland Druze. In: Gubrium, J.F. (ed.): Time, roles and self in old age. New York: Human Sciences Press.

Gaarder, J. (1996): Vita Brevis. Floria Aemilias brev til Aurel Augustin. Oslo: Aschehoug.

Hansen, B. og Trana, H. (1994): Det verdige moderskap i etterkrigstiden. Tidsskrift for Norsk Psykologforening, 31, 797-816.

Havens, B.J. (1968): An investigation of activity patterns and adjustment in an aging population. Gerontologist, 8 , 201-206.

Hellevik, O. (1996): Nordmenn og det gode liv. Norsk monitor 1985-1995. Oslo: Universitetsforlaget.

Ingebretsen, R. og Thorsen, K. (1990): Kvinner blir gamle. Om aldring, overganger og mestring av selvbildet. In: Ingebretsen, R. og Thorsen, K. (eds.): Kvinner blir gamle. NGI-rapport 3-1990. Oslo: Norsk gerontologisk institutt.

Inglehart, R. (1990): Culture shift in advanced industrial society. Princeton: Princeton University Press.

Jung, C.G. (1960): Det ubevisste. København: Gyldendal.

Kaufman, S.R. (1986): The ageless self. Sources of meaning in late life. Madison: University of Wisconsin Press.

Kohut, H. (1971): The Analysis of the Self. New York: International Universities Press.

Kohut, H. (1977): The Restoration of the Self. New York: International Universities Press.

Kohut, H. (1977/1986): Att bygga upp självet. Lund: Bokförlaget Natur och Kultur. Første utgave: The Restoration of the Self. New York: International Universities Press.

Kohut, H. (1984): How does analysis Cure? (Eds. Goldberg, A. and Stepansky, P.E.) Chicago: University of Chicago Press.

Kristeva, J. (1982): Powers of Horror. An Essay on Abjection. New York: Columbia University Press.

Lowenthal, M. Boler, E. (1965): Voluntary vs. involuntary social withdrawal. J Gerontol, 263-271.

Lutz, C.A. (1988): Unnatural Emotions. Chicago: The University of Chicago Press. 
Mauss, M. (1990): The Gift: the Form of Reason for Exchange in Archaic Societies. London: Routledge (1st edition 1954).

Mead, G.H. (1934): Mind, Self and Society. Chicago: Chicago University Press.

Mellbye, F. (1991): Fra planlegger til bruker av eldreomsorg. In: Gerontologiske skrifter nr. 3: Aldring - generasjonsforskjeller, kjønnsforskjeller og planlegging av eldreomsorg. Oslo: Norsk selskap for aldersforskning.

Næss, S. (1979): Livskvalitet. INAS-rapport 2:79. Oslo: Institutt for anvendt sosialforskning.

Peck, R.C. (1968): Psychological development in the second half of life. In: Neugarten, B.L. (ed.): Middle age and aging. Chicago: University of Chicago Press.

Polkinghorne, D.E. (1991): Narrative and Self-concept. J Narrative Life Hist, 1 (2-3), 135-153.

Scheff, T.J. (1990): Microsociology. Chicago: University of Chicago Press.

Shotter, J. (1984): Social Accountability and Self-hood. Oxford: Blackwell.

Sundström, G. (1994): Åldrandet: Skojigt eller hopplöst? Aldring og Eldre, 2, 30-32

Swane, C.E. (1996): Hverdagen med Demens. Billeddannelser og hverdagserfaringer i kulturgerontologisk perspektiv. København: Munksgaard.

Søndergaard, D. (1996): Kroppen i psykologien, subjekt og/eller objekt? Prøveforelesning for den filosofiske doktorgrad, oppgitt emne. Universitetet i Oslo: Det samfunnsvitenskapelige fakultet, 15. mars 1996.

Thielst, P. (1984): Følelsernes idehistorie - nogle mønstre og eksempler. Psyke og Logos, $\mathbf{5}, 1$.

Thorsen, K. (1992): Livsløp og alderdom. Kvinneliv og mannsliv - gamle forteller sin livshistorie. NGI-rapport 61992. Oslo: Norsk gerontologisk institutt.

Thorsen, K. (1995). Aldring - den doble forandringen. Et selv $i$ sin tid. NGI-rapport 3-1995. Oslo: Norsk gerontologisk institutt.

Thorsen, K. (1996): Kjønn, livsløp og alderdom. Det samfunnsvitenskapelige fakultet, Unversitetet i Bergen. (Fagbokforlaget 1998)

Tornstam, L. (1973): Att åldras; Socialgerontologiska perspektiv. Avhandling, Universitetet i Uppsala, Sociologiska institutionen.

Tornstam, L. (1989): Gero-transcendence: A meta-theoretical reformulation of the disengagement theory. Aging, 1, 55-63.

Tornstam, L. (1991): Gerontologins quo vadis - om det gerontologiska forskningsparadigmet. Socialmedicinsk tidsskrift, 2-3.

Tornstam L. (1992a): Aldrandets socialpsykologi, 4. utg. Stockholm: Raben \& Sjögren.

Tornstam, L. (1992b): Gerotranscendence - empirical evidence of a new theoretical concept. Universitetet i Uppsala: Sociologiska institutionen.

Tornstam, L. (1992c): Gerotranscendence. Gerontologia, 5, 317-319.

Tornstam, L. (1994): Gerotranscendence - A theoretical and empirical exploration. In: L.E. Thomas, S.A. Eisenhandler (eds.): Aging and the Religious Dimension. Westport: Greenwood Publishing Group.

Tornstam, L. (1996): Caring for elderly. Introducing the theory of gerotranscendence as a supplementary frame of reference for the care of the elderly. Scand J Caring Sci, 10, 144-150.

Tornstam, L. Kirk, H. (1988): Gero-transcendens - omformulering av teoriene om tilbaketrekning. Gerontologi og Samfund, 4, 64-65 (Also printed in Tidsskrift for sygeplejeforskning, 1991, 1, 72-79).

Widding Isaksen, L. (1992): Kroppsnärheten förklarar omsorgsarbetets låga status. Kvinnovetenskaplig tidsskrift, 4, 14-19.

Wouters, C. (1992): On status competition and emotion management: The study of emotion as a new field. Theory, Culture and Society 9, 229-252.

Wærness, K. (1996): "Omsorgsrasjonalitet." Reflexioner över ett begrepps karriär. In: Eliasson, R. (ed.): Omsorgens skiftninger. Lund: Studentlitteratur.

Øberg, P. (1995): The Absent Body - A Social Gerontological Paradox. Universitetet i Uppsala: Sociologiska Institutionen.

Øvrelid, B. (1996): Notid og framtid: Dei små forteljingane, dei lokale sanningane og det postmoderne. In: Holter (ed.): Hun og han. Kjønn i forskning og politikk. Oslo: Pax Forlag. 